\title{
Toward a Definition of Realism in the African Context
}

\author{
Mineke Schipper
}

I N DIFFERI N I limes and cultures, "realitv" is experienced and expressed by artists and writers in different ways. Reality and knowledge about it are sociallv determined and therefore relative. Our problem is here: How and to what degree does the writer succeed in making us believe that literature "copies" reality?

The aim of the realistic writer is constant: to write. with respect to the valid norms of his time. more veraciously and to put reality more directly into words than his predecessors have done. The word realism. however, has been so randomly applied to all sorts of texts and literatures that we must very carefully define our use of it. The question remains how realistic literature succeeds in producing an "effect of reality."

Realism does not just mean "true to the hard facts." It is not possible to determine it quantitatively in the sense of the more facts in a text, the more realistic the text will be. What is true is not always probable (in the sense of credible) - and therefore realistic - in the eyes of the reader. who uses his own experience of reality as a

\section{touchstone.}

The realistic writer destroys certain norms of his time (and his social group) in writing more truthfully than his predecessors. Therefore Harry Levin called the literary realisı "a professional iconoclast. bent on shattering the false images of his dav."]

Sometimes the destruction of norms in the realistic novel only stı ikes the literary svstem. but in many cases it also touches the social and political svstem. A concrete historical situation, a datable and locatable frame are conditions for the realization of realism. The urge for liberty, which is often associated with the rise of a class or group, and the "view from below" of society are realistic features as well. These constitute .1 latent threat to the existing order and the ruling authority. Censorship, persecution, or imprisonment are there to prove that the writer's realism can be effective. that this verbalized reality has been recognized (but not accepted) by the authorities. This is not a phenomenon of the past, as appears from the numerous cases of dissident and imprisoned writers in our own time. throughout the 
world, who describe their contemporary reality so realistically that the political authorities experience their writings as too recognizable and therefore as threatening. There are the many bans on realistic black writers in South Africa and the well-known case of Ngugi wa Thiong'o's imprisonment in Kenya.

In the author's point of view toward reality, there are two main possibilities: (1) He believes in the existence of reality in itself as an object of knowledge, and he feels confident about knowing and representing it even better than other writers have done before him. (2) He does not believe in the existence of objective reality. Such is the case in Western Europe, where there has been a growing uncertainty among writers and intellectuals about the human possibility of objective perception since the beginning of the century. Language, according to the latter, seems inadequate and insufficient to imitate "objective" reality. As a result, the writer fixes his attention on his own person: he believes that the only reality left is the one he experiences in his own consciousness. The intersubjective dimension gets lost in the view of such authors who no longer believe in the possibility of describing the world outside. They withdraw into a personal consciousness without any concrete reality context.

My starting point is that only the first conception-the author's belief that reality exists in itself as an object of knowledge and that it is possible to represent it "as it is" in literature - is to be called realistic and its product realistic literature. After these preliminary remarks, we'll now turn to the author's realistic intentions, themes, and techniques in the African novel in general and to the case of the Senegalese writer Sembène Ousmane and his Les bouts de bois de Dieu (God's Bits of Wood) in particular.

The theme of Africa and the African has been frequently used in European exotic and colonial literature. It has inspired many European writers with all the stereotypes and exoticism it entailed. Emmanuel Obiechina ascertained that a novel like Daniel Defoe's The Life, Adventures, and Piracies of the Famous Captain Singleton (1720) already "embodies most of the stereotypes which were to characterize later European writing on Africa." "More and more fascinated by the African theme, many European writers gradually considered themselves "specialists on Africana." However, these novels did not yield any "real" information about Africa. Professor Echeruo stated rightly in Joyce Cary and the Novel of Africa that "if there is anything 'true' of such novels, it is not essentially (or properly) in its setting or in its depiction of character and personality, but in the accuracy of its reflection of the imaginative temper of the author's culture."3

It was against this exotic and colonial perspective in the European 
novel about Africa that the first generation of African novelists started to present their own version of the same theme: the confrontation between Africans and Europeans in Africa. The white, prejudiced norms had to be destroyed: according to the African perspective, the European colonial literature had not dealt realistically at all with the theme of Africa. This has often been confirmed by African writers themselves. The case of Chinua Achebe is well known: one of his reasons for starting to write was to correct Joyce Cary's eurocentric vision of Africa in a novel like MisterJohnson, set in Nigeria. As he put it in an interview: "This was a most superficial picturenot only of the country, but even of the Nigerian character, and so I thought if this was famous, then perhaps someone ought to try and look at it from the inside." 4

Achebe also attacked the views of Joseph Conrad in his essay "An Image of Africa," where he concluded that Conrad was "a bloody racist" and that "this simple truth is glossed over in criticisms of his works due to the fact that white racism against Africa is such a normal way of thinking that its manifestations go completely undetected. The real question is the dehumanization of Africa and Africans which this age-long attitude has fostered and continues to foster in the world. And the question is whether a novel which celebrates this dehumanization, which depersonalizes a portion of the human race, can be called a great work of art. My answer is: No, it cannot." 5

Reasoning along the same lines, many African writers wanted to give their own views on the European presence in Africa and the colonial "reality." Later, other realistic themes were chosen in conjunction with contemporary society. The European character no longer played the important part it had in African literature (especially in the francophone novel about the colonial era) for some time. In the sixties this radically changed. Other themes became central in the novels of African writers, who were more and more preoccupied with their own present society - with all the risks their criticism implied. They committed themselves to criticize the social norms upheld by a new group, the political authorities of their own countries. Broaching new themes, they destroyed at the same time the convention of formerly fashionable themes like the image of the European, the colonial times, and the precolonial African paradise, as I have examined in my book Le Blanc vu d'Afrique. ${ }^{6}$

In Africa, the first generation of novelists reacted in various ways to the prevailing European conceptions of culture and civilization and the romantic view of Africa by "a fictional documentation of cultural and sociological details," as Dan Izevbaye put it in an interesting article entitled "Issues in the Reassessment of the African Novel." Their 
"narrative strategy" reminded this Nigerian critic of the way Western realist writers reacted to European Romanticism in literature in the nineteenth century. ${ }^{7}$ Of course, the essential difference is the fact that the destruction of norms did not occur in the same cultural context as in Europe between Romantics and realists in the European nineteenth century.

How is the difference to be described? For the European critic, unfamiliar with the African cultural background, the "otherness" of the depicted milieu, customs, everyday life, and so forth, had the effect of a continual flow of sociological information in fictional form, an effect it did not necessarily have in Africa. Izevbaye made the point that an African would notice a comparable abundancy of sociological details in European novels. One simply overlooks this fact when familiar with a cultural context. Especially one's own is taken for granted by the reader: "For any one of Sir Walter Scott's historical novels of Scotland or the fairly contemporary account of London life which we find in Virginia Woolf's Mrs. Dalloway, a truly African reader-if it were possible for him to read English without a good knowledge of its cultural background-would require as full a glossary as the average English reader would need to enter the literary world of The Interpreters and Petals of Blood." In European as well as in African literature, the "sociological" information has to be brought into line with the other elements of the literary text. The author's information, his "file cards," should not be too evident as such. If they are, "sociology" has not been forged into literature. The answer to the question of whether an author has succeeded in creating a literary text depends on the reader's criteria, which-as we have seen-not only depend on his own cultural background but also on the sociological knowledge he has about the cultural background of the literary text.

Many African novels refer "realistically" to African history, mainly recent history. They often do this quite directly, mentioning historical names and places, referring to well-known events like wars, battles, conflicts, strikes, and the like. This is what Philippe Hamon, in his essay on realism, has called "mega History," the corresponding real history which doubles the (illusion of) reality of the literary text. ${ }^{9}$ There are many examples of such references, whether in East, West, or Southern Africa. One might think of Sembène Ousmane's L'Harmattan (1964), which is completely based on the theme of the "Referendum" of 1958 organized by the French authorities in order to keep the French colonies under French rule, and the struggle of the young Africans against the voting in favor of the new Constitution and the French Communauté. The novel is preceded by a very inter- 
esting preface by the author, who states: "I do not practice the theory of the novel. Yet I remember that in the olden times the storyteller was not only the dynamic element of his tribe, clan, village, but also the patient witness of each event. He was the one who recorded, putting down, in front of all, under the palaver tree, everybody's doings. The idea of my work derives from this teaching: to keep as close as possible to reality and the people." 10

One of the chapters of L'Harmattan is entitled "Le Referendum" and the historical date is stated: 28 September 1958. It is then related how the people had been bribed to vote "yes" by gifts of wine and beer, money, French flags, and the women in particular by kilometers of material with the printed image of General de Gaulle to dress themselves in favor of the French Government (pp. 285 f.).

Another well-known example comes from Kenya on the eve of Independence: Ngugi's A Grain of Wheat (1967). In this novel there are frequent historical references to the colonial times, the Resistance, the Mau Mau movement, the fight for freedom, the "Party," the World Wars, the Queen of England, leaders like Harry Thuku and Jomo Kenyatta, the ceremony of Independence itself. Two fragments:

So in Harry Thuku, people saw a man with God's message: Go unto Pharaoh and say unto him: let my people go. And people swore they would follow Harry through the desert. ...

But the whiteman had not slept. Young Harry was clamped in chains, narrowly escaping the pit into which Waiyaki was buried alive. Was this the sign they waited for? People went to Nairobi; they took an oath to spend their days and nights outside the State House till the Governor himself gave them back their Harry.

Warui, then a young man, walked all the way from Thabai to join the procession. He never forgot the great event. When Jomo Kenyatta and other leaders of the Party were arrested in 1952, Warui recalled the 1923 Procession.

"The young should do for Jomo what we did for Harry. I've never seen anything to match the size of that line of men and women," he declaimed, gently plucking his beard. ${ }^{11}$

In this quotation the historical facts are related to the memories and experiences of the people in general and those of the characters in the novel in particular. In the second example, the importance of real history as a factual frame of reference for the personal story is obvious. The fourteenth chapter tells about the ceremonies of Independence. The author first presents his "file cards" of the real objective facts, how it went in reality, how it has been told in the 
newspapers. In the next section the narrator, changing from third person to first person narrative voice, recalls his own experiences, the Independence (Uhuru) festivities in the village:

Kenya regained her Uhuru from the British on 12 December 1963. A minute before midnight, lights were put out at the Nairobi Stadium so that the people from all over the country and the world who had gathered there for the midnight ceremony were swallowed by the darkness. In the dark, the Union Jack was quickly lowered. When next the lights came on the new Kenya flag was flying and fluttering, and waving in the air. The Police band played the new National Anthem and the crowd cheered continuously when they saw the flag was black, and red and green. The cheering sounded like one intense cracking of many trees, falling on the thick mud in the stadium.

In our village and despite the drizzling rain, men and women and children, it seemed, had emptied themselves into the streets where they sang and danced in the mud. (P. 177)

The "authenticity" of history emphasizes indeed the effect of reality on the reader: this is how it went, the author seems to say, on the general and the personal level-let there be no doubt about it.

In the historical framework which is so often alluded to in the African novel, the author then situates the weal and woe of the group which lives the historical events in its own community: the traditional village in Camara Laye's L'enfantnoir (1953) or Chinua Achebe's Things Fall Apart (1959), Ferdinand Oyono's Le vieux negre et la medaille (1956) or Ngugi's A Grain of Wheat (1967). Of course, the traditional community is only one of the possible themes. We also meet communities in the cities - for example, small groups of progressive youngsters as in Sembène Ousmane's L'Harmattan; or trade union leaders in his Les bouts de bois de Dieu, who confront the assimilated majority; or groups of colonial whites as they are so unforgettably depicted, for instance by the Cameroonese writers Oyono and Beti, but one finds them as well in Ngugi's and other East African writings and, of course, in many South African novels. Other groups include the students, the politicians, the businessmen, the new elite.

In his interesting book The Novel and Contemporary Experience in Africa, Shatto Arthur Gakwandi distinguished two types of realism:

The first type concerns itself primarily with the behaviour of man, the individual being treated as an autonomous entity. The second type takes the whole breadth of society as its subject matter and examines how the customs, conventions, social institutions and individuals inter-relate. The first type is what has come to be known as psychological realism, the second as social realism. With social realism, the individual is treated as a social unit; most 
often he is silhouetted against the institutions, traditions and general behaviour of his society so as to underscore his insignificance. His aspirations, achievements and disappointments are seen as conditioned by his place in a given society and can be used to raise wider ethical, moral and social issues.

Social realism became a major fictional technique in nineteenth century Europe and it may be said to constitute the central inheritance of the African novel from its European ancestor. In essence and technique the African novel has borrowed heavily from the European novel.... the leading African novelists have been satisfied with employing the techniques developed by European realism and having used them to comment upon African experience. ${ }^{12}$

The techniques of this social realism are now to be described in the African novel. Are the above-mentioned general characteristics of the European (mostly nineteenth-century) realistic novel really the "unaltered basic forms with a local colour" the African novelists worked with, as Gakwandi believed? Or is there something else to be seen as well? It seems most practical to turn now directly to the author chosen for our purpose and generally recognized as an African realist: Sembene Ousmane, and more specifically to one of his novels, Les bouts de bois de Dieu. We'll look first at the author's intention, his use of "mega History," the social context and the setting of his works. Afterwards, we'll turn to the techniques, language and, later, intertextuality in his novel.

In an interview I had with Sembene Ousmane some years ago, I asked him whether his work is to be viewed as belonging to socialist realism. His answer was no, because he felt socialist realism belonged to the socialist countries only, although he had nothing against the movement: "What I want to represent is a social realism. I have no intention of creating great heroes, on the contrary, I am concerned with everyday reality, the woman who struggles for life and toils to nourish her child, her sorrows, her hopes. I work with the material of everyday life of ordinary people. They recognize themselves in my works and identify with my characters." For Sembene Ousmane, there is no question about the describability of reality. He believes in it, and he sees it as the task of the writer to put reality into words "as it is":

The African writer must stand in the midst of society and at the same time observe this reality from the outside.... I participate in the developments of society and note these. I am a fighter, I know what I want to change in society and this facilitates my work as a writer. You are right in stating that my works develop along with the society in which I live, with its ups and downs, its defeats and its victories.... We started from a colonial system. 
This system is now partially hidden behind the façade of the black bourgeoisie. My work as a writer is narrowly associated with the struggle for real independence. In Africa we first thought that in 1960 with Independence paradise would come. Now we know belter. The whites have led indeed, but those in power now behave in exactly the same way.... We are faced with the realitv of our own bourgeoisie in power which wants to be exactly like the white bourgeoisie. These people are eas $\backslash$ accomplices of imperialism in Africa. We must have the courage to denounce their practices.

These quotations make the author's perspective on reality quite clear. Ever since he started to write novels, he has wanted to describe the social reality of everyday life and has referred to concrete historical situations in a datable and locatable frame.

Le docker non (1956) depicts the life of the black dockers in the port of Marseille and the French racist society. All Ousmane's other novels are situated in Africa. Before the historical context of Independence, () pays, mon beau peuple (1958) is set in the Casamance in Senegal; Les bouts de bois de Dieu in the cities of Bamako, Thiès. and Dakar: L'Harmattan (1964) in an unnamed African francophone countrv voting in favor of the Referendum of 1958. In Xala (1973) we meet the postIndependence African bourgeoisie in the well-to-do businessman El Hadji Abdou Kader Bèye and his colleagues. K.I Hadji's "xala" (Wolof word for impotence) svmbolizes the bourgeoisie's impotence in dealing honestly with its deprived fellow citizens. It is interesting to see how Sembene himself explains the meaning of this last novel with respect to today's African reality:

Xala is, in a certain way, the storv of a true segment of history: the history of the contemporary bourgeoisie of the Third World whose representatives have, after the past struggle against colonialism. turned themselves into new classes which can onlv imitate the bourgeoisie from the Western world. . . I wanted to emphasize that only the masses possess the real solution to our problems. That is the meaning of the lası scene: von have to spit on the new bourgeoisie and to vomit on them, starting with ridiculing them. This is our indispensable task if we want the neu Africa we dream of to become real.

Sembene Ousmane's intention as an author is quite clear: he wants to show the real Africa, his Africa-that is, the people's Africa. According to him, the only thing writers or filmmakers are entitled to do if they want to be social realists is to reflect the ordinary people and their problems.

This leads us to the sociat context of his works. In the framework of contemporary or immediate history in practically all his works, he refers to concrete events in the setting his characters move around 
in. These characters are portrayed in their milieu and linked to social groups which are in opposition to one or more other social groups in the novel. Thus we meet for example the black dockers versus the racist French, or the progressive youngsters versus the assimilated, corrupted African clergymen and politicians in L'Harmattan. or the employers versus the employed in Les bouts de bois de Dieu, or the rich elite versus the army of the poor in Xala. Of course, there are many more oppositions between different social reference groups than the ones I mention here.

In all Sembene Ousmane's novels we see the urgefor liberty and the efforts of a rising group viewing society from below, that is, from the side of the oppressed who react to their situation, be it as blacks or as workers, as women or as youngsters, in their opposition to whites or bosses or husbands or the elder generation. Like many other African authors of his generation, Sembene Ousmane feels committed to portraying African life as an integrated reality viewed from the inside and from the people's perspective. Listening to the people is essential for him. or, in his own words: "I put to the test the impact of what I have written, I want to verify the truth. I spend hours discussing with the people . . . especially on very precise points. Thus, I have learnt a lot, especially from the peasants." Sembene Ousmane does not pretend to work for the people, but he wants to belong to the people ("non pas travailler pour le peuple, mais rester du peuple").

Next question: Where is his work to be situated in the historical evolution of literary and social features? There are several lines meeting at a crossroads: literary lines, cultural lines, ideological lines, and so forth. There is first of all the oral literature line. In the interview I had with him, he answered my question about the function of oral literature for modern African literature as follows: "Oral literature is vanishing. The modern writers are turning to it more and more as a source of inspiration. However, we must not forget contemporary reality, and let us no longer dream sentimentally about clear old Africa in the past, like some people, especially Europeans, still do. Very soon Africa will no longer oralls transmit its old stories to the younger generations. On the one hand this is sad, of course, but on the other hand it is very comprehensible: ... the ambition of the young generation reaches much farther than the horizon of the village."

Obviously, Sembene Ousmane grants a less important function to the oral tradition than a number of other African writers. It might entail the danger of concealing contemporary realitv as he wants to reveal it in his novels and films. Nevertheless, the oral tradition line is present in his works in the language of the characters who represent the old people. We'll come back to this point later, when we 
discuss intertextuality. Oral literature in his view will be increasingly replaced by the modern media like radio, film, television. Effectiveness, the link with the largest possible audience, is what counts most. A book has more readers than an oral tradition in the village has spectators, but a film has a larger audience than a book has readers, especially in Africa. This made Sembene Ousmane say that for him today "the cinema replaces the palaver tree."

The other literary line is the line of written literature, especially the novel. Sembene Ousmane has been influenced by Western novelists: the French, such as Balzac, Zola, and Flaubert, and the Russians Dostoevsky, Gogol, and Chekhov. It is the line of the traditional European novel, not the experimental nouveau roman genre, which would not at all correspond with the author's intention of reaching a large audience. 13

Sembene Ousmane is mostly an autodidact. After primary school he received his trade union training, so that he has not been very much influenced by the "intellectual milieus in France," as were those African writers with a university education. Sembene Ousmane considered the Paris intellectuals to be "too bourgeois" to be interesting. ${ }^{14}$

A next step is to find out which norms Sembene Ousmane destroyed by writing his novels. First of all, the literary norms: being a writer and partly influenced by the West, his novels constituted a break with tradition, from the African point of view, by their form. As far as the literary themes were concerned, his novels reacted against the norms of the European exotic and colonial novels about Africa. Secondly, the destruction of the social and political norms of the ruling classes - first of the Western colonial rulers, then of the African elite in power: Sembene Ousmane's perspective is not the power perspective but the people's view of African society.

Our next question is: How is the author's information about his reality - the "truth" as he called it-conveyed throughout the text? In order to answer this, we'll try to describe the realistic devices he uses in his novel Les bouts de bois de Dieu.

Sembene Ousmane describes the weal and woe of the group whose "truth" he wants to reflect: the community life, its social coherence, the fact of belonging to the same clan, class, nation, or continent. In this respect, the author's note to Les bouts de bois de Dieu is significant: "The men and women who, from the tenth of October, 1947, to the nineteenth of March, 1948, took part in this struggle for a better way of life owe nothing to anyone: neither to any civilizing mission nor to any parliament or parliamentarian. Their example was not in vain. Since then, Africa has made progress." 15 At the same time this note announces the "mega History" which doubles and predetermines the 
text, referring closely to the well-known historical "facts" and consequently creating a clear pattern of expectation in the reader's mind.

Another realistic aspect of this note is its authenticatingfunction: thus the author guarantees the truthfulness of the story beforehand. The beginning of a realistic text often has such a "probabilizing" function, being a foreword, a dedication (Sembène Ousmane dedicates his book as follows: "For you, GOD'S BITS OF WOOD, and for my comrades in the unions," underlining once more its truthfulness), a first paragraph, a footnote on the first page, and so forth.

The above-mentioned author's note has yet another function: it is a good example of the prediction device, one of the common realistic techniques in the novel. Here the note announces the story's happy ending; it is full of confidence in the future of Africa. The historical time of the author's writing is the fifties, that is, before Independence. Other devices of prediction, foreshadowing developments in the text, include the lucidity of the leader Bakayoko, the group awareness of the railway workers and the African community, the fixing of the syndicalists' negotiation program, and the counterprojects of the white inhabitants of the quarter called "The Vatican."

On the other hand, numerous flashbacks are there to give concrete information and to strengthen the coherence of the text. They are produced in various forms. Some take the form of memories-for instance, old Niakoro's memories right in the beginning about the previous strike of 1938, in which she had lost a husband and a son; or Doudou's memories at the moment of meeting Isnard, who tries to bribe him (pp. 2, $146 \mathrm{ff}$.). Other flashbacks take the form of summanes of past events. Sometimes a chapter begins that way-for example, the chapter entitled "Tiémoko" (p. 78) or the one called "The Meeting" (p. 203). We also find flashbacks in the form of references to an ancestor, a clan, the mentioning of heredity, a tradition, or a family: the case of Ad'jibid'ji and her mother, for instance:

Ad'jibid'ji must have been eight or nine years old, but she was tall for her age. She had the same features as Assitan, her mother, and the same fine nose, for they were nobly descended, from the Peuls and the Berbers. (P. 4)

By the ancient standards of Africa, Assitan was a perfect wife: docile, submissive, and hard working. . . . One night her father had told her that her husband was named Sadibou Bakayoko, and two months later she had been turned over to a man whom she had never before seen. The marriage had taken place with all of the ceremony required in a family of ancient lineage, but Assitan had lived only eleven months with her husband when he was killed in the first strike at Thiès. Three weeks later she had given birth to a daughter, and once again the old customs had taken control of her life; she 
had been married to the younger Bakayoko, Ibrahim. He, in turn, had adopted the baby and given her her curious name, Ad'jibid'ji. Assitan continued to obey. With the child, and the child's grandmother, Niakoro, she had left Thies to follow her husband to Bamako. She was as submissive to Ibrahim as she had been to his brother. (P. 106)

The interrelationships are very close, generally speaking, not only within the small family circle - as in the European realistic novelbut in the whole community. It is social realism indeed, because the characters function as social units in the present as defined by their historical condition. The social units meet in this novel in their function as trade unionists, as a group of white colonials, as members of the same family, as neighbors in a township, as old people, women, or prisoners.

As readers we are introduced to scenes in which the characters manifest their belonging to their social group(s) by their language as well as by their behavior. Thus we are informed about the different social groups. The names are also significant: on the African side, we find African names - and for those who know the respective languages, differences will be noticed between Bambara and Wolof names, like Bakayoko, Niakoro, Boubacar, Penda; in the white group we find French names like Dejean, Monsieur Edouard, Leblanc, Dr. Michel, Beatrice, and so forth.

It is not only characters' names that refer to "reality," but also names of places like Dakar (n'Dakarrou), Thies, Bamako, Le Vatican, France, Les Vosges. Such geographical names are to be recognized as proper names by the way they are written with capitals. They are not necessarily followed by descriptions, because the proper names of places are able to guarantee the reference effect by themselves. Besides the denotation of such proper names referring to the context in a direct and literal way, they are at the same time heavily loaded with connotations full of social content: this is already clear in the implications of the use of African and French names, respectively. The names are associated with milieus and activities. The colonial whites are neither workers nor syndicalists; they are not victims of inequality and do not suffer materially from the strike. The Africans are just the opposite. This is what Hamon called "onomastic transparence." 16 It is reinforced by the filling in of the characters and milieus. In the realistic novel, this leads to the creation of social types and characteristic behavior in professional activities as well as in the couleur locale setting. Here, the realistic writer sees his opportunity to convey part of his knowledge about African social life, groups, trade, milieus, and so forth, to the readers. He wants to convince the 
reader of the authenticity of the information within the framework of the story and keeps himself outside. Therefore "specialized" characters are introduced to present or represent a milieu, a situation, a profession.

Niakoro, for example, represents the old African woman, her way of thinking, her behavior, her reactions in the African community where tradition is no longer respected as much as before. N'Deye Touti is the prototype of the French-influenced young generation of African schoolgirls, while Beatrice Isnard has all the characteristics of the white colonial woman.

The same holds true for the men: Bakayoko is the social type of the male visionary leader - almost too romantically idealized to be realistically acceptable. Two other types: Hadrame the Moor, the shopkeeper, and the white "commandant" of the detention camp, Monsieur Bernadini-but there are many more examples in this novel. Here is one example from the text to illustrate the way it works: one of the women, Ramatoulaye, has decided to go and find food for her twenty "bits of wood." She enters the shop of Hadrame the Moor, the "hen roost," as it is called, "because of the dirt that pervaded everything in it." The detailed description of the shop starts at the moment Ramatoulaye enters. Later, other bits of information are given in between her conversation with the shopkeeper:

There were three entrances from the street, and an enormous wooden counter, covered with a mixture of grease and dust, ran the entire length of the store. On either side of a haberdashery showcase there were scales, of different sizes. At one end of the counter there were fly-specked jars of sweets, and at the other a sort of cage of metallic gauze, containing loaves of stale bread. A cockroach was climbing slowly up its inner frame. The whole rear wall of the shop was covered by rickety shelves, held together with wire and piled with rolls of cloth of every kind, from the cheapest calicoes to silks, side by side with boxes of candles and squares of tallow. Between the counter and the row of shelves there was a narrow pathway, littered with bags of rice and salt and cases of tinned sardines and tomatoes. The floor surrounding the big cask of oil was thick with grease. And, as if this glut of merchandise was not enough, Hadrame had succeeded in wedging three tailors into a corner at the back. They sat in the shop all day, measuring, cutting, and sewing. (P. 41)

Hadramé is clearly the type of shopkeeper who only thinks of his own interests. His behavior is adequately described in the scene following the shop description.

Exactly the same method is applied in the presentation of the Corsican Bernadini. Before we see him in action, the detention camp is 
described, first from the outside, then from the inside, at the moment when old Fa Keita is locked up and joins the other prisoners. Setting followed by action is also the order in which the "Vatican" and its inhabitants are presented (see pp. $162 \mathrm{ff}$.). The combination of setting description and a character's adequate behavior contributes highly to the "probability" of the story. One of the elements in this probabilizing technique is what one could call the "pretext function," that is, the motivation of the information by (1) the attentive look- for example, Ramatoulaye's entering Hadramé's shop; (2) the explanatory speech: the trial of Diara the ticket collector is a good example (pp. 91 ff.); (3) the technical act: Niakoro designing a gourd (p. 3) or Bernadini torturing the prisoners (pp. $231 \mathrm{ff}$.).

All this is utilized by the realistic writer who wants his text to be an "ostentatious discourse of knowledge" (the "descriptive file card," knowledge being equal to reality) "which must be shown to the reader." 17 Thus the realistic writer conceals his pedagogical intention and his well-documented file card system and technical vocabulary behind his characters' conversation and behavior in their own environment. Of course, the three above-mentioned motivations - the attentive look, the speech, and the technical act-are often combined for the same purpose. Sometimes look and speech manifest themselves in a sort of pseudomonologue in a semidirect style (for example, Sounkaré, the Watchman [pp. $127 \mathrm{ff}$.$] ).$

One might wonder to what degree such characters are functional actors in the story and to what degree they are no more than agents of communication, transmitters of information. Hamon qualified them as "defunctionalized characters" from the narrative point of view. ${ }^{18}$ If reality is knowledge for the realistic writer, the constraint is evident: the characters constantly risk being sacrificed for the benefit of the distribution of the author's knowledge.

Miracles, doubts, uncertainties, ambiguities, ironies are problematic in a way because they can be detrimental to the seriousness of the story. This clearly distinguishes the realistic text from "strange," "marvelous," and fantastic literature, where such devices are optimally exploited. ${ }^{19}$ Les bouts de bois de Dieu is an unambiguous text. For the purpose of neutralizing his information, the realistic author often aims at keeping himself as well as the reader outside the text, suggesting therewith perfect objectivity. However, this leads to that other constraint, the problem of the hero in the realistic novel. The constraint consists in realism requiring the absence of a genuine (idealized and/ or romantic) hero on the one hand, and the literary text needing one for its coherence and readability on the other. Now, the central character of Les bouts de bois de Dieu is Bakayoko, but this militant leader 
is often kept offstage. For realistic reasons? Probably. The reason might well be to compensate for the romantic, epic, almost mythical features the author also clearly wants to attribute to this character. The list of personages is quite long; there are more than forty in all: the social group is more important than the individual character. In my opinion, Sembene has often succeeded in keeping the "realism balance" of his novel stable, especially through the device of the characters' defocalization - that is, the shifting of point of view among the different characters. In the field of narratology one can ask two questions as far as the relation between narrator and characters is concerned: Who speaks? and Who sees? The first question concerns narration, the second focalization. The narrator tells the story, but at the same time the events and situations are presented from a specific perspective, a point of view, and this is not necessarily the narrator's. The subject of focalization is called the focalizer. ${ }^{20}$ It is important to distinguish between the two, because focalization or shifting of focalization contributes to the effect a character has on the reader. We must be aware of it because if we are not, our opinions are easily manipulated. When the story is presented from the point of view of a character (that is, when he is the focalizer), we are easily inclined to share views or to sympathize with him or her. Technically speaking, the focalization might be to his advantage, if a view is presented via this character only. There are stories in which we only meet one character-focalizer all through the text, which consequently leads to partiality and restriction. This is for instance the case in Mongo Beti's Poor Christ of Bomba, where we are only allowed to see the events from Denis's particular point of view, although the reader will do more with the given information than this narrator-character does. All the same, this has a special effect on the reader.

More often than not, the focalization shifts from one character to another or from narrator to character(s) in a novel. In this way we get a rather good idea of the various sides of a conflict or confrontation. This technique leads to or at least suggests neutrality vis-a-vis the different characters and their relations. The realistic writer will often use defocalizations for his own purposes, and Sembene Ousmane has not hesitated to do so. There is shifting in all his novels, but Les bouts de bois de Dieu is certainly one of the clearest examples of the kind: right from the beginning one finds focalization shifting from narrator to the character and vice versa. In the first chapter, for instance, we first look at the setting with the narrator, then focalization shifts to Niakoro, after that to Ad'jibid'ji, and so on, creating the effect of reality and "objectivity."

To conclude, I should like to mention another very important real- 
istic technique Sembene Ousmane uses effectively: language. The realistic writer is forced to bring his personal style into harmony with the different sociolects of his characters (which require the actual effacement of his personal style). As we said, Sembene Ousmane always stressed the importance of the writer's being of the people and not writing/or the people. The interesting thing is that his personal style is very close to the ordinary everyday language of the African community he lives in, thus creating an effect of coherence. On the other hand, he also handles quite easily other languages, such as the syndicalists' jargon and the white colonial sociolect, knowing the former from his long trade union experience and the latter from having lived half his life under colonial rule.

The only possible "literal," concrete imitation of reality is in fact the imitation of language. This brings us to the phenomenon of intertextuality. ${ }^{21}$ Out of different oral and written "texts" (fixed forms of language) a new text has been forged which lays claim to unityit is an intertext, the result of an intertextual process. In a text, different sociolects meet, reinforce, or confront each other-for example, greetings, religious formulas, songs, stories, speeches, novel forms - the use of which is no longer the same: they have new functions in the new text. All these parts of the intertext share the feature that they refer to similar "texts" in reality, "texts" which express social, ideological, and historical positions. The text is based on a variety of these positions, as a realistic text should be. Constituting a multicolored mosaic of sociolects, each referring to a specific group in reality, the denotation is quite easy, but denotating does not cover the whole signification of the text. The very fact of intertextuality, the being together in one coherent text, brings about lots of connotations at the same time, similarities and oppositions being created by this very fact.

Unfortunately, I cannot go into that subject in this limited paper, but I am convinced that interesting possibilities for research are to be discovered in this direction. Interesting and useful-not only in the field of realism and the African context.

FREE UNIVERSITY, AMSTERDAM

\section{NOTES}

1 Harry Levin, "On the Dissemination of Realism," in Grounds for Comparison (Cambridge, Mass., 1972), p. 248.

2 Emmanuel Obiechina, Culture. Tradition and Societv in the West African Novel (Cambridge, 1975), p. 18.

3 Michael J. C. Echeruo, Joyce Cary and the Novel of Africa (London, 1973), p. 5. 
4 Dennis Duerden and Cosmo Pieterse, African Writers Talking (London, 1972), p. 4.

5 Chinua Achebe, "An Image of Africa," Research in African Literatures, 9 (1978), 9.

6 Mineke Schipper, Le Blanc vu d'Afrique (Yaounde, 1973).

7 Dan Izevbaye, "Issues in the Reassessment of the African Novel," African Literature Today, 10 (1979), 15.

8 Izevbaye, p. 16.

9 Philippe Hamon, "Un discours contraint," Poétique, No. 16 (1973), pp. 411-45. This is a most interesting article on the techniques of realism.

10 Sembene Ousmane, "Advertissement de l'Auteur." L'Harmattan (Paris, 1964), p. 1. 11 Ngugi wa Thiong'o, A Gram of Wheat (London, 1967), p. 13.

12 Shatto Arthur Gakwandi, The Novel and ContemporaryExperience in Africa(London, 1977), pp. 126-27.

13 Lilyan Kesteloot, Les ecrvvains nours de languefraçaise: nanssance d'une htterature (Brussels, 1963), pp. $283 \mathrm{ff}$.

14 Kesteloot, p. 432.

15 Sembene Ousmane, Les bouts de bois de Dieu (Paris, 1960), p. 7; hereafter cited in text (quotations from English translation, God's Bib of Wood, tr. Francis Price [London, 1969]).

16 Hamon, p. 427.

17 Hamon, p. 432.

18 Hamon, p. 431.

19 See Tzvetan Todorov, Introduction a la littérature fantastique (Paris, 1970).

20 See Gerard Genette, "Discours du récit," in Figures III (Paris, 1972), pp. 183-267.

21 For the concept of intertextuality, see, e.g., Laurent Jenny, "La stratégie de la forme," Poétique, No. 7 (1976), pp. 257-81; Jonathan Culler, "Presupposition and Intertextuality," in The Pursuit of Signs (Ithaca, N.Y.. 1983), pp. 100-118. 